\title{
RECHTSREGEL
}

Jurnal Ilmu Hukum Vol 1, No 1 Agustus 2018

P-ISSN 2622-6235, E-ISSN 2622-6243,

rjih_fh@unpam.co.id

\section{FIDUSIA SEBAGAI LEMBAGA JAMINAN ATAS TAGIHAN KREDIT PEMILIKAN RUMAH PADA PASAR SEKUNDER}

\author{
Ginung Pratidina \\ Fakultas Hukum, Universitas Pamulang \\ Email : gp hukum@gmail.com
}

Received: - /Revised: - /Accepted: Ags 2018

\begin{abstract}
Salah satu lembaga jaminan yang dikenal masyarakat Indonesia adalah fidusia, lembaga jaminan ini dikenal di Indonesia berdasarkan yurisprudensi Hooggrechshof (HGH) atas perkara Bataafsche Petroleum Mastschappij dengan Clignet Arrest. Pada perkembangannya fidusia mengalami perubahan yang sangat pesat dari segi benda jaminannya hal ini karena kebutuhan masyarakat akan lembaga jaminan fidusia ini, baik dari transaksinya maupun dari kebutuhan kepastian hukumnya.Undang-undang Nomer 42 tahun 1999 tentang Jaminan Fidusia (selanjutnya disebut UUJF) memberikan kepastian hukum pada perjanjian utang pitang yang jaminannya bersifat fidusia. Undang-undang tersebut mengatur pelaksanaan jaminan fidusia, namun demikian masih perlu diuji berlakunya karena perkembangan kepentingan dunia usaha dalam menjaminkan barang modalnya sebagai jaminan utangnya untuk mendapatkan pinjaman sebagai modal usaha. Pada akhirnya perjanjian utang piutang yang jaminannya bersifat fidusia tidak menutup kemungkinan adanya konstruksi hukum baru. Hal ini bisa dilihat dari bergesernya obyek benda jaminan yang awalnya hanya berupa benda bergerak saja, pada akhirnya benda yang bersifat ekonomis baik benda yang sudah ada maupun benda yang akan ada dapat dijadikan obyek jaminan fidusia. Diantara benda jaminan tersebut adalah piutang atas Kredit Pemilikan Rumah yang diselenggarakan oleh pihak Bank, konstruksi hukum yang terbentuk adalah debitor dan kreditor antara nasabah dan Bank penyelenggara Kredit Pemilikan Rumah dengan dasar itulah Bank penyelenggara Kredit Pemilikan Rumah yang memiliki hak tagih atau piutang ke nasabah yang dijadikan jaminan atas pinjaman kepada Secondary Mortgage Facility ( selanjutnya disebut SMF).
\end{abstract}

Kata kunci : Fidusia, perjanjian, jaminan. 


\begin{abstract}
One of the security agency, known by Indonesian society is fiduciary, insurance agency is known in Indonesia by Jurisprudence Hooggrechshof (HGH) for cases Bataafsche Petroleum Mastschappij with Clignet Arrest. In the development of Fiduciary would change very rapidly in this because its guarantee thing society needs Fiduciary institution, both of the transaction and of the need for legal certainty.The Act Number 42 Year 1999 above Fiduciary Security (hereinafter referred to as UUJF) provide legal certainty to guarantee the debt agreement is fiduciary. These laws regulate the implementation of the Fiduciary, however, still needs to be tested into effect due to the development in the interests of both business capital goods pledged as collateral to get a loan as debt capital. At the end of the guarantee agreement debts are Fiduciary did not rule out the construction of the new law. It can be seen from the shift of objects objects originally just a guarantee that any moving object, the objects that were ultimately economical existing objects or objects that will no be subjected Fiduciary. Among the objects are collateral receivables on mortgage loans held by the Bank, which formed the legal construction is the debtor and creditor between the customer and the Bank Housing Loan providers on the basis that the organizers Bank mortgage loans that have a right to collect or claim to be customers collateral for loans to the Secondary Mortgage Facility (hereinafter referred to as SMF).
\end{abstract}

Keywords: Fiduciary, agreements, guarantees

\title{
PENDAHULUAN
}

Sebelum diundangkannya Undang-undang Jaminan Fidusia ,lembaga jaminan ini dikenal berdasarkan yurisprudensi Bataafshe Petroleum Maatschappij (BPM) - Clignett Arrest berdasar keputusan Hooggerechtshof (HGH) yang dikeluarkan tanggal 18 Agustus 1932. Sejak diundangkannya Undang Undang nomor 42 tahun 1999 Tentang Jaminan Fidusia (selanjutnya disebut UUJF), pada tanggal 30 September 1999. Masyarakat menyukai adanya lembaga jaminan fidusia, karena: 
1. Barang agunan yang dijaminkan masih dikuasai oleh debitor bahkan barang tersebut merupakan alat utama dalam melakukan usaha.

2. Barang agunan berupa barang hasil pertanian

3. Tidak semua hak atas tanah dapat dijadikan obyek hak tanggungan

4. Barang bergerak yang bukti kepemilikannya belum dikuasai misalnya : barang dagangan.

Untuk fidusia dasar terjadinya transaksi adalah kepercayaan, maka perjanjiannya mendasarkan pasal 1338 ayat 3 Burgerlijk Wetboek (selanjutnya disebut $B W$ ) : " Perjanjian harus dilaksanakan dengan itikad baik." Setelah diundangkannya UUJF kedudukan kreditor dapat lebih terlindungi kepentingannya, hal ini tercermin dari beberapa hal berikut:

1. Pasal 4, sifat dari perjanjian fidusia adalah asesor dalam undang-undang disebut perjanjian ikutan dari perjanjian pokok artinya sebelum perjanjian pokok lunas termasuk segala akibatnya, hak agunan yang timbul dari akibat penyerahan jaminan fidusia tidak dapat dihapuskan, termasuk jika piutang dialihkan ke kreditor lain

2. Pasal 5 angka 1, bentuk perjanjian fidusia harus tertulis yang dibuat dengan akta notaris dalam bahasa Indonesia dan merupakan akta Jaminan Fidusia, hal ini mempunyai kekuatan hukum sebagai alat bukti bagi para pihak maupun pihak ketiga.

3. Pasal 11 angka 1, pasal 12 angka 1 dan pasal 13 angka 1 , perjanjian fidusia harus didaftar dan dicatatkan hal ini untuk memberikan kepada penerima fidusia hak kebendaan atau hak agunan yang memiliki hak mendahului atau preferensi, seperti 
ini penting karena untuk keperluan agunan bagi pelunasan utang.

4. Pasal 35, ada unsur pidana bagi para pihak yang tidak beritikad baik.

Segala benda bergerak yang memiliki nilai ekonomi bisa dijadikan obyek jaminan fidusia. Seperti pasal 1 angka 4 tentang UUJF menyebutkan :" Benda adalah segala sesuatu yang dapat dimiliki dan dialihkan, yang berwujud maupun yang tidak berwujud, yang terdaftar maupun yang tidak terdaftar yang bergerak maupun tidak bergerak yang tidak dapat dibebani hak tanggungan atau hipotik.". Sehingga di ketentuan tersebut diketahui bahwa obyek jaminan fidusia sangat sulit ditentukan kriterianya mengenai kewenangan atas alas hak benda tersebut, karena keadaan ini menyangkut tentang barang jaminan fidusia dimana barang tersebut masih dikuasai oleh debitor. Sehingga penerima fidusia tidak memiliki hak mutlak, tetapi hak kepemilikan dengan hak menyerahkannya kembali kepada pemberi fidusia untuk keperluan penerima fidusia. Ketentuan angka 1 dan 2 Pasal $1320 B W$ menyangkut obyek yang diperjanjikan. Penentuan ini penting artinya karena obyek perjanjian bisa berupa apapun seperti yang disebutkan pada pasal $1131 \mathrm{BW}$, segala harta kekayaan seorang debitor, baik yang berupa benda-benda bergerak maupun benda-benda tetap, baik yang sudah ada maupun yang baru akan ada dikemudian hari, menjadi jaminan semua perikatan utangnya. Ketentuan ini mengatur dengan asumsi jika hanya terdapat satu debitor dan satu kreditor, jika hal ini terjadi pada debitor pailit yang mana kreditornya lebih dari satu maka bisa dilihat pada ketentuan pasal $1132 \mathrm{BW}$, harta kekayaan debitor itu menjadi jaminan secara bersama-sama bagi 
semua kreditor yang memberi utang kepada debitor yang bersangkutan dan hasil dari penjualan benda-benda yang menjadi kekayaan debitor itu dibagi kepada semua kreditornya secara seimbang atau proporsional menurut perbandingan besarnya piutang masing-masing kecuali apabila diantara para berpiutang ada alasan-alasan yang syah untuk didahulukan. Ketentuan pasal $1132 B W$ tersebut bisa ditafsirkan bahwa kreditornya bisa lebih dari satu sehingga ada kreditor yang didahulukan dari kreditor lainnya apabila ada ketentuan yang ditentukan oleh Undangundang. Alasan-alasan yang dimaksudkan pasal $1132 B W$ terdapat pada pasal $1133 B W$. Menurut pasal $1133 B W$, hak untuk didahulukan bagi seorang kreditor tertentu terhadap kreditorkreditor lain timbul dari Hak Istimewa, Gadai dan Hipotik. Tentang hal urutan hak untuk didahulukan yang timbul dari ketiga hak tersebut menurut pasal $1134 B W$ adalah gadai dan hipotik lebih tinggi daripada Hak Istimewa, kecuali dalam hal-hal yang oleh Undang-undang ditentukan sebaliknya. Kreditorkreditor yang tidak mempunyai hak untuk didahulukan terhadap kreditor-kreditor lain disebut kreditor konkuren sedangkan kreditor yang mempunyai hak untuk didahulukan terhadap kreditor-kreditor lain disebut kreditor preferen.

Tentang hak tanggungan yang diatur di Undang-undang Nomor 4 tahun 1996 tentang Hak tanggungan Atas Tanah (selanjutnya disebut UUHT). Beserta Benda-benda yang berkaitan dengan Tanah, yang disahkan pada tanggal 9 April 1996. Pada pasal 1 ayat 1 UUHT memberikan definisi sebagai berikut :

“ Hak Tanggungan adalah Hak Jaminan yang dibebankan pada hak atas tanah sebagaimana dimaksud dalam Undang-undang Nomor 5 Tahun 1960 tentang Peraturan Dasar Pokok-pokok 
Agraria, berikut atau tidak berikut benda-benda lain yang merupakan satu kesatuan dengan tanah itu, untuk pelunasan utang tertentu, yang memberikan kedudukan yang diutamakan kepada kreditor tertentu terhadap kreditor lain"

Selanjutnya kita bandingkan pengertian hak tanggungan tersebut dengan pasal $1162 B W$ yang mendefinisikan sebagai berikut : " Hipotik adalah suatu hak kebendaan atas benda-benda tak bergerak, untuk mengambil penggantian dari padanya bagi pelunasan suatu perikatan.”

Sehingga timbul permasalahan yang harus diselesaikan yakni apa konstruksi hubungan hukum para pihak dalam kredit Pemilikan Rumah pada Pelaksanaan Pasar Sekunder Pembiayaan Perumahan?

\section{PERMASALAHAN}

Sehingga timbul permasalahan yang harus diselesaikan yakni apa konstruksi hubungan hukum para pihak dalam kredit Pemilikan Rumah pada Pelaksanaan Pasar Sekunder Pembiayaan Perumahan?

\section{METODOLOGI PENELITIAN}

Penulis akan menjawab permasalahan yang timbul mengenai hubungan hukum para pihak dalam perjanjian kredit tersebut dengan melakukan penelitian hukum (Legal Research) yakni penelitian yang didasarkan pada suatu prosedur penelitian ilmiah untuk menemukan kebenaran berdasarkan logika hukum secara normatif, logika hukum dibangun berdasarkan disiplin ilmiah dan cara kerja ilmu hukum yang obyeknya adalah ilmu hukum itu sendiri.

Dengan melakukan pendekatan konseptual (conceptual approach) dari pendapat para ahli hukum perjanjian dan hukum 
jaminan yang terkait topik penulisan jurnal serta pendekatan perundang-undangan (statute approach) karena penelitian ini juga melakukan kajian-kajian norma hukum perjanjian dan norma hukum jaminan terutama yang berkaitan langsung dengan undang-undang Jaminan Fidusia serta undang-undang lainnya yang ada kaitannya dalam penulisan jurnal.

Menurut pasal 1320 BW angka 4 menjadi dasar hukum eksistensi asas kebebasan berkontrak, yang mana para pihak yang membuat dan mengadakan perjanjian diperbolehkan untuk menyusun dan membuat kesepakatan atau perjanjian yang melahirkan kewajiban apa saja, selama dan sepanjang prestasi yang wajib dilakukan tersebut bukanlah sesuatu yang terlarang. Selain pasal 1320 BW tersebut diatas pasal 1339 BW juga bisa dijadikan dasar hukum dari kebebesan berkontrak, adapun pasal 1339 BW menyebutkan sebagai berikut : “ Perjanjian-perjanjian tidak hanya mengikat untuk hal-hal yang dengan tegas dinyatakan didalamnya, melainkan juga untuk segala sesuatu yang menurut sifat perjanjian diharuskan oleh kepatutan, kebiasaan, atau undang-undang." Hal ini menyangkut tentang isi perjanjian atau obyek yang diperjanjikan sehingga para pihak akan terikat dengan hak dan kewajiban untuk memenuhinya. Mengenai obyek perjanjian menyangkut jaminan kebendaan BW membedakan menjadi :

1. Kebendaan berwujud dan tidak berwujud

2. Kebendaan bergerak dan tidak bergerak

3. Kebendaan yang habis dipakai dan tidak habis dipakai

4. Kebendaan yang sudah ada dan akan ada

5. Kebendaan dalam perdagangan dan yang akan diperdagangkan 
6. Kebendaan dapat dibagi dan tidak dapat dibagi

Secara umum hukum jaminan diatur pasal 1131 BW, segala benda milik debitor baik yang bergerak, baik yang sudah ada maupun yang baru akan ada dikemudian hari, menjadi tanggungan jaminan bagi semua perikatan utangnya. Tentang apabila debitor tidak bisa melunasi utangnya maka benda yang dijaminkan akan dijual dan dibagi secara proporsional kepada kreditornya seperti yang diatur pasal 1132 BW sebagai berikut, harta kekayaan debitor menjadi jaminan secara bersama-sama bagi semua kreditor yang memberi utang kepada debitor yang bersangkutan, pendapatan penjualan benda-benda itu dibagi-bagi menurut keseimbangan yaitu menurut besar kecilnya piutang masing-masing, kecuali apabila diantara kreditor ada alasanalasan yang sah untuk didahulukan. Hal ini sesuai dengan pasal 1 angka 2 Undang-undang Nomor 42 tahun 1999 tentang Jaminan Fidusia yakni: “...yang memberikan kedudukan yang utama kepada Penerima Fidusia terhadap kreditor lainnya."

Pada jaminan fidusia juga dikenal dengan hak preferensi artinya jika debitor jatuh pailit, pihak penerima fidusia terlebih dulu menerima pelunasan utangnya yang diambil dari penjualan barang obyek fidusia, hak ini juga dimiliki para kreditor lainnya yang memiliki hak tanggungan. Jaminan fidusia wajib didaftarkan seperti halnya diatur pasal 11 UUJF, hal ini dilakukan untuk menjamin kedudukan hukum bagi pemberi fidusia. Karena dengan didaftarkan dan dipublikasikan pendaftarannya maka obyek jaminan bisa diketahui oleh khalayak umum jika benda tersebut dibebani dengan jaminan fidusia.

Peraturan Presiden Nomor 19 tahun 2005 tentang Pembiayaan Sekunder Perumahan pasal 1 angka 11 disebutkan 
Pembiayaan Sekunder Perumahan adalah penyelenggaraan kegiatan penyaluran dana jangka menengah dan/atau panjang kepada Kreditor asal dengan melakukan sekuritisasi. Selanjutnya pasal 1 angka 14 menyebutkan sekuritisasi adalah transformasi aset yang tidak liquid menjadi liquid dengan cara pembelian asset keuangan dari kreditor asal dan penerbit efek beragun aset. Pelaksanaan Pembiayaan Sekunder Perumahan ini berasal dari Pasar Modal yang mana Pasar Modal itu terdiri dari pasar perdana dan pasar sekunder. Pasar sekunder adalah pasar yang terjadi karena proses transaksi jual beli efek antar investor yang mana efek-efek tersebut telah tercatat di bursa. Dari pasar sekunder inilah mobilisasi dana pembiayaan perumahan terjadi, untuk pelaksanaan pasar pembiayaan sekunder perumahan dilakukan oleh suatu lembaga yang didirikan khusus untuk itu, seperti yang diatur dalam Peraturan Presiden Nomor 19 tahun 2005 tentang Pembiayaan Sekunder Perumahan pasal 3. Tujuan khusus dari pembentukan SMF ini yang merupakan pasar sekunder dimana SMF tidak diperkenankan untuk bergerak pada kegiatan keuangan riil. Sehingga dalam menjalankan kegiatannya SMF hanya bertindak sebagai pembiayaan kepada bank yang menyelenggarakan program KPR. Hubungan hukum yang terbentuk antara SMF dan Bank penyelenggara KPR adalah kreditor dan debitor dengan perjanjian utang piutang dengan jaminan tagihan Bank penyelenggara KPR terhadap nasabahnya. Piutang yang dijaminkan tersebut termasuk benda bergerak yang tak berwujud yang merupakan salah satu kriteria hak kebendaan yang dapat dijadikan jaminan yang bersifat Fidusia. 


\section{PEMBAHASAN}

\section{Perjanjian Hutang Piutang}

Pasal $1233 B W$ menyebutkan:" tiap-tiap perikatan dilahirkan baik karena persetujuan baik karena undang-undang”. bahwa perikatan itu timbul maka ada konsekwensi hukum bahwa adanya dua pihak yang masing-masing pihak karena perikatan tersebut mempunyai hak dan pihak lain mempunyai kewajiban yang mana harus dilaksanakan sesuai dengan perikatan yang telah disepakati. Pasal $1233 B W$ tersebut diatas dipertegas dengan pasal $1234 B W$ yang menyatakan:" Tiap-tiap perikatan adalah untuk memberikan sesuatu, untuk berbuat sesuatu atau untuk tidak berbuat sesuatu." Sehingga perikatan menimbulkan hak dan kewajiban di lapangan hukum kekayaan, para pihak dengan sukarela membuat perjanjian yang mana dengan perjanjian tersebut mengikatkan diri satu sama yang lain untuk berbuat sesuatu atau tidak berbuat sesuatu dalam memenuhi hak dan kewajibannya.

Sedangkan yang dimaksud dengan lapangan kekayaan adalah perjanjian yang berkaitan dengan perjanjian yang berhubungan dengan harta kekayaan seseorang, seperti pasal 1131 BW yang menyatakan : Segala kebendaan milik debitor, baik yang bergerak maupun yang tidak bergerak, baik yang sudah ada maupun yang baru akan ada dikemudian hari, menjadi tanggungan untuk segala perikatannya seseorang." Dengan demikian sangatlah jelas bahwa dalam ilmu hukum diatur secara tegas bangunan hukum atau konstruksi hukum beserta akibat hukumnya sehingga kegiatan yang mengharuskan para pihak untuk membuat perikatan harus dilandasi dasar kepentingan yang dilindungi oleh undang-undang. 


\section{Unsur Perikatan}

Adanya unsur hukum berarti seseorang dalam bertindak harus memenuhi kriteria hukum yang mensyaratkan untuk sahnya perbuatan itu dimata hukum, baik hukum yang memaksa maupun akibat hukum dari tindakan tersebut. Mengenai unsur kekayaan atau harta, bahwa kekayaan tersebut identik dengan harta atau kebendaan yang bisa diperjanjikan atau obyek dari perjanjian. Dengan adanya para pihak sebagai subyek hukum dalam pelaksanaan pembuatan perikatan maka dengan demikian unsur subyektif dari perikatan sudah terpenuhi karena inisiatip dari terbentuknya perikatan adalah para pihak yang secara hukum sudah diakui sebagai subyek hukum. Unsur lain yang harus terpenuhi dalam perikatan tersebut adalah prestasi atau juga yang disebut hak dan kewajiban dari para pihak untuk dilaksanakan.

\section{Bentuk Perikatan}

Bentuk perikatan adalah sebagai berikut:

1. Perikatan bersyarat yaitu perikatan tersebut masih digantungkan pada suatu peristiwa yang akan datang

2. Perikatan dengan ketetapan waktu yaitu perikatan yang pelaksanaannya ditangguhkan

3. Perikatan mana suka atau alternatif yaitu perikatan yang memberikan kebebasan yang berutang untuk memberikan atau menyerahkan sesuatu barang dari beberapa jenis yang mesti harus diserahkan.

4. Perikatan tanggung menanggung yaitu perikatan di salah satu pihak terdiri dari beberapa orang yang mana secara bersama berkewajiban memenuhi seluruh prestasi kepada pihak lain. 
5. Perikatan yang dapat dibagi dan tidak dapat dibagi yaitu perikatan yang membagi prestasinya saja sekedar perimbangan yang tanpa mengurangi hakekat prestasinya.

6. Perikatan dengan ancaman hukuman yaitu perikatan yang mengharuskan salah satu pihak untuk melaksanakan prestasinya dengan ancaman hukuman jika tidak melaksanakan prestasi.

Meskipun perikatan dapat diklasifikasikan seperti tersebut diatas namun ada asas yang berlaku dalam perikatan yakni asas konsesualism yakni untuk membuat perikatan harus ada konsensus atau kesepakatan bersama yang dituangkan dalam perjanjian artinya dua belah pihak telah sepakat terlebih dahulu.

\section{Keabsahan Perjanjian}

Dalam perjanjian utang piutang ada para pihak yang mempunyai kewajiban, kreditor atau yang berpiutang dan debitor atau yang berutang dan kemungkinan dari para pihak ini digantikan posisinya oleh pihak lain. Hal demikian ini bisa terjadi pada pihak debitor maupun pihak kreditor, namun ada ketentuan jika yang digantikan adalah debitor maka penggantian posisi oleh debitor lain harus mendapat persetujuan dari kreditor agar kreditor bisa menilai kemampuan debitor baru dalam menyelesaikan kewajibannya. Namun jika penggantian dipihak kreditor maka tidak diperlukan persetujuan dari debitor, juga dalam perikatan hal yang biasa jika perikatan tersebut terdiri dari beberapa kreditor dan beberapa debitor. Mengenai posisi pihak kreditor maupun debitor menurut Mariam Darus Badrulzaman dalam perikatan bisa dikemukakan sebagai berikut :

1. Sekurang-kurangnya ada satu kreditor 
2. Kreditor yang ditentukan atau dikenal maka kreditor demikian memiliki gugatan atas nama

3. Penggantian kedudukan kreditor atau peralihan hak atas prestasi terjadi dengan melakukan suatu formalitas tertentu misalnya dengan akta yaitu akta cesie.

4. Kreditor bisa mengalihkan haknya kepada kreditor baru, hak mana adalah merupakan hak-hak pribadi yang kwalitatif.

5. Peralihan posisi kreditor bisa juga terjadi dengan subrogasi.

Disisi debitor dijelaskan sebagai berikut :

1. Dalam perikatan setidaknya ada satu debitor

2. Penggantian debitor harus mendapat persetujuan dari kreditor

3. Debitor dapat terjadi karena perikatan kwalitatif.

Jika melihat kondisi penggantian subyek perikatan yang demikian seperti tersebut diatas mencerminkan bahwa asas kebebasan berkontrak memang teruji, hal demikian seperti apa yang ditentukan pada pasal $1320 B W$ angka 4 . Kondisi ini sangat diperlukan bagi praktisi usaha guna menampung maksud dan tujuan dari para pihak untuk mendapat kepastian hukum.

\section{Obyek perjanjian}

Obyek perjanjian ini sangat penting artinya karena mempengaruhi bentuk perjanjian dan akibat hukum yang sangat mendasar. Mengenai obyek perjanjian menyangkut jaminan ini perlu disampaikan bahwa menyangkut jaminan kebendaan ini Buku II $B W$ membedakan menjadi :

1. Kebendaan berwujud dan tidak berwujud

2. Kebendaan bergerak dan tidak bergerak

3. Kebendaan yang habis dipakai dan tidak habis dipakai

4. Kebendaan yang sudah ada dan akan ada 
5. Kebendaan yang dapat diperdagangkan dan tidak dapat diperdagangkan

6. Kebendaan yang dapat dibagi dan tidak dapat dibagi

Obyek perjanjian diatas menyangkut bagaimana cara pengikatan dan bagaimana cara penyerahan yang harus dilakukan oleh pihak yang harus melakukan prestasi, sehingga bisa ditentukan bentuk perjanjian yang harus dilakukan karena menyangkut pada lembaga jaminan yang bisa menjamin kepastian hukum dari bentuk dan penyerahan obyek perjanjian.

Perubahan-perubahan posisi dari pihak debitor dan kreditor, menimbulkan konstruksi hukum baru dari suatu perjanjian serta adanya perubahan prestasi dari para pihak. Pada perubahan posisi yang semula adalah sebagai kreditor pada kredit pemilikan rumah yang pada proses pembiayaan kreditor berubah kedudukan sebagai debitor dikarenakan hak tagih pada debitor dijadikan sebagai jaminan untuk pembiayaan kredit pemilikan rumah. Untuk memenuhi kebutuhan akan permodalan pembiayaan kredit pemilikan rumah pihak kreditor bisa mendapatkan pembiayaan lewat pasar sekunder. Pasar sekunder merupakan suatu lembaga dimana para pemodal bisa bertemu dalam suatu komunikasi transaksi keuangan untuk menempatkan dananya pada pihak yang memerlukan pendanaan dalam bidang usahanya. Pelaku usaha bisa melakukan transaksi keuangan sesuai dengan peraturan yang telah disepakati di pasar sekunder. Dengan adanya suatu konstruksi hukum baru dari peralihan kreditor lama menjadi debitor baru, membawa konsekwensi hukum baik terhadap debitor lama maupun posisi debitor baru terhadap debitornya, ataupun kreditor baru terhadap debitor lama yang harus melaksanakan prestasinya terhadap kreditor lama meskipun 
sudah berubah posisi menjadi debitor baru. Tentunya hal demikian menjadi peristiwa hukum yang harus diantisipasi akibat hukumnya apalagi perubahan posisi tersebut menyangkut perjanjian dengan pengikatan secara fidusia.

\section{Sifat dan Perjanjian Fiducia}

Hak jaminan timbul karena adanya perjanjian pemberian jaminan yang mengikuti perjanjian utang piutang, adanya perjanjian pokok atau perjanjian utama dan ada perjanjian tambahan atau perjanjian asesoir. Pasal $1313 \mathrm{BW}$ dasar dari terjadinya perjanjian dan pasal $1320 B W$ dasar keabsahan dari perikatan dengan dasar pada pasal-pasal tersebut bahwa telah teruji jika pembuatan perjanjian mempunyai asas kebebasan berkontrak atau ada juga yang menyatakan perjanjian menganut sistim terbuka artinya bahwa hukum perjanjian memberikan kebebasan untuk mengadakan perjanjian dengan ketentuan kebebasan tersebut tidak melanggar ketertiban umum dan kesusilaan dengan kata lain tidak melanggar undang-undang.

\section{Hubungan fidusia dengan hukum perikatan}

Pasal 1 angka 1 UUJF menyatakan bahwa Fidusia adalah pengalihan hak kepemilikan suatu benda atas dasar kepercayaan dengan ketentuan bahwa benda yang hak kepemilikannya dialihkan tersebut tetap dalam penguasaan pemilik benda. Pasal 1 angka 2 UUJF memberikan pengertian tentang benda jaminan yang bisa dijadikan jaminan dalam lembaga jaminan Fidusia serta kedudukan kreditor. Kreditor perlu jaminan sebagai pemberi pinjaman kepada debitor maka perjanjian utama dari perjanjian fidusia ini adalah perjanjian utang piutang, yang dimaksud dengan jaminan adalah jaminan untuk pelunasan utang debitor. 


\section{Bentuk Perjanjian Fiducia}

Pasal 5 angka 1 UUJF menyebutkan, pembebanan Benda dengan Jaminan Fidusia dibuat dengan akta notaris dalam bahasa Indonesia dan merupakan akta Jaminan Fidusia.

Ketentuan mengenai perjanjian fidusia dibuat tertulis bermakna sebagai berikut :

1. Karena benda jaminan secara nyata masih dikuasai oleh debitor maka dengan perjanjian fidusia dibuat tertulis maka kreditor bisa mempertahankan haknya atas benda yang dijaminkan tersebut terhadap pihak III

2. Dengan tertulis maka antara debitur dan kreditor bisa menuangkan hak dan kewajibannnya yang diatur oleh hukum.

3. Sebagai pembuktian kepada ahli warisnya seandainya debitur meninggal dunia.

\section{Hak Tanggungan dan Hak Kebendaan Dalam Fidusia Sebagai Lembaga Jaminan.}

Pasal $1131 B W$ menyatakan bahwa segala kebendaan debitur baik yang bergerak maupun yang tidak bergerak baik yang sudah ada maupun yang baru akan ada dikemudian hari menjadi tanggungan untuk segala perikatan. Pasal $1132 \mathrm{BW}$ menyatakan bahwa kebendaan tersebut menjadi jaminan bersamasama bagi semua orang yang mengutangkan padanya, pendapatan penjualan benda itu dibagi-bagi menurut keseimbangan, yaitu menurut besar kecilnya piutang masing-masing kecuali diantara para berpiutang ada alasan yang sah untuk didahulukan. Kedua pasal tersebut diatas merupakan dasar hukum jaminan umum dimana pasal $1132 \mathrm{BW}$ adalah jaminan untuk perikatan utang 
piutang. Dalam hal bentuk jaminan bisa dibedakan sebagai berikut

\section{Jaminan Umum}

Seperti yang telah disampaikan pasal 1131 BW dan Pasal 1132 $B W$ bahwa benda bergerak maupun yang tidak bergerak, baik yang sudah ada maupun yang baru akan ada dikemudian hari bisa dijadikan jaminan perikatan utang piutang. Karena kreditor lebih dari satu maka seluruh barang jaminan dari hasil penjualan dibagi berimbang menurut besar kecilnya piutang masing-masing.

2. Jaminan khusus

Untuk menjamin kedudukan kreditor terhadap barang jaminan, kreditor menghendaki adanya penunjukkan secara khusus barang jaminan piutangnya, diatur pasal $1133 \mathrm{BW}$ dan $1134 B W$

3. Jaminan yang bersifat kebendaan

Jaminan yang berupa hak mutlak atas suatu benda yaitu hak kebendaan yang mempunyai hubungan langsung atas benda yang dijaminkan oleh debitor yang dapat dipertahankan terhadap siapapun dan selalu mengikuti bendanya dan dapat dialihkan.

4. Jaminan hak perorangan

Ialah jaminan yang menimbulkan hubungan langsung pada perorangan tertentu terhadap kekayaan debitor.

5. Jaminan atas benda bergerak

Jaminan atas utang debitor adalah benda-benda bergerak, dapat dijadikan obyek jaminan perikatan gadai dan fidusia.

6. Jaminan yang menguasai bendanya 
Untuk pengamanan pembayaran kembali utang maka dapat diberikan jaminan menguasai barang jaminan bisa dilakukan pada gadai

7. Jaminan tanpa menguasai bendanya

Jaminan yang benda jaminannya masih dikuasai debitur hal ini bisa dilakukan pada fidusia.

Dalam hukum jaminan sangat penting mengetahui pembedaan benda jaminan ini karena menyangkut cara-cara penyerahan dari benda-benda yang dijadikan jaminan.

Untuk pembedaan barang tersebut dapat diperinci sebagai berikut

1. Benda tak bergerak menurut sifatnya, misalnya : tanah dan segala sesuatu yang melekat diatasnya.

2. Benda tak bergerak karena tujuannya, misalnya mesin-mesin pabrik

3. Benda tak bergerak menurut ketentuan undang-undang, hal ini berwujud hak-hak atas benda-benda tak bergerak.

Pembedaan benda bergerak :

1. Pasal $509 B W$ menyatakan benda bergerak karena sifatnya ialah benda yang dapat berpindah dan dipindahkan

2. Pasal $511 B W$ menyatakan hak-hak kebendaan atas benda yang bergerak karena undang-undang.

Pasal 1 angka 2 UUJF mengelompokkan benda bergerak dan tidak bergerak serta benda berwujud dan tidak berwujud namun tidak dijelaskan apa yang dimaksud mengenai benda berwujud dan benda tidak berwujud. Demikian pula di $B W$ tidak memberikan penjelasan tentang benda tidak berwujud semisal pasal $503 B W$ menyatakan tiap-tiap kebendaan adalah bertubuh 
atau tidak bertubuh, maksud dari pasal tersebut adalah berwujud dan tidak berwujud.

Selain pasal $503 \quad B W$ tersebut pasal-pasal yang menyebutkan istilah kebendaan tidak berwujud :

1. Pasal 613 mengatur tentang pemindahan hak milik atas kebendaan tidak berwujud

2. Pasal 614 mengenai hak memungut hasil atau bunga

3. Pasal 1158 tentang gadai atas piutang

4. Pasal 1164 tentang hipotek atas hak-hak tertentu

Benda-benda tak berwujud adalah hak-hak termasuk didalamnya yang diatur pasal $508 B W$ yaitu kebendaan tidak berwujud yang termasuk kedalam kebendaan tidak bergerak, diatur juga dalam pasal $511 B W$ yaitu kebendaan tidak berwujud yang termasuk dalam kebendaan bergerak. Diluar ketentuan pasal-pasal tersebut diasumsikan sebagai benda berwujud.

Salah satu hak yang masuk pada bentuk kebendaan yang bisa dijadikan jaminan ialah benda bergerak yang tidak berwujud yaitu piutang, yang mana piutang merupakan salah satu hak yang bisa dijadikan jaminan fidusia, karena piutang termasuk benda bergerak yang karena penetapan undang-undang, seperti yang ditentukan pasal 511 angka $3 B W$ yang menyatakan perikatanperikatan dan tuntutan-tuntutan mengenai jumlah-jumlah uang yang dapat ditagih atau mengenai benda-benda bergerak.

Dari pasal $613 B W$ bisa dijelaskan bahwa ada 3 jenis piutang yaitu

1. Piutang atas nama yaitu pengalihan terhadap piutang dengan akta otentik atau dibawah tangan, pengalihan mana termasuk hak-hak kebendaanyang melekat padanya. 
2. Piutang atas bawa yaitu pengalihannya dilakukan hanya dengan penyerahan surat piutang tersebut.

3. Piutang atas tunjuk yaitu pengalihannya dilakukan dengan penyerahan surat piutang disertai endosemen (tulisan atau tanda tangan di belakang surat tersebut).

Pasal 9 UUJF mengelompokkan piutang menjadi :

1. Piutang yang telah ada

2. Piutang yang akan diperoleh kemudian.

Jika disandingkan antara ketentuan $B W$ dan UUJF tersebut diatas maka piutang dari ketentuan $B W$ sangat tidak mungkin untuk dijadikan jaminan fidusia, karena pada fidusia penyerahannya dengan cara constitutum possessorium. Hal ini karena piutang atas tunjuk dan piutang atas bawa tidak hanya merupakan bukti bahwa pemegangnya adalah yang berhak, namun juga merupakan wujud dari piutang tersebut. Sementara itu mengenai ketentuan UUJF memberikan peluang mengenai piutang yang bisa dijadikan jaminan adalah yang sudah ada maupun piutang yang akan diperoleh kemudian berarti walaupun diperoleh kemudian piutang tersebut tidak dibuat dalam perjanjian tersendiri tetapi termasuk dalam perjanjian jaminan fidusia yang dibuat pada saat jaminan diberikan karena sudah dilakukan pengalihan hak kepemilikan atas benda tersebut seperti yang dinyatakan dalam akta jaminan fidusia pada obyek piutang. Hubungan antara nasabah dan bank tersebut menimbulkan hak dan kewajiban yakni karena nasabah menerima kredit dari bank maka nasabah mempunyai kewajiban untuk mengangsur utangnya sesuai yang telah disepakati sedangkan bank mempunyai hak menerima pembayaran kembali utang nasabah dengan kata lain bank mempunyai hak tagih dari nasabah. Piutang bank terhadap nasabahnya inilah yang dijadikan 
jaminan kepada pihak ketiga yaitu pada lembaga Keuangan Non Bank yang bergerak di bidang Pembiayaan Sekunder Perumahan yang diatur berdasarkan Peraturan Presiden RI Nomor 19 Tahun 2005 tentang Pembiayaan Sekunder Perumahan dan diperbarui dengan Peraturan Presiden RI Nomor 1 tahun 2008 tentang perubahan atas Peraturan Presiden Nomor 19 tahun 2005 tentang Pembiayaan Sekunder Perumahan atau Secondary Mortgage Facility (selanjutnya disebut SMF). SMF inilah yang memberikan pinjaman kepada bank penyelenggara Kredit Pemilikan Rumah dengan jaminan hak tagih atau piutang kepada nasabahnya yang berutang terhadap bank tersebut. Dengan demikian maka posisi bank penyelenggara KPR dari kreditor menjadi debitor atas perjanjian pinjaman yang dibuat dengan SMF. Pasal 4 UUJF menyatakan, Jaminan Fidusia merupakan perjanjian ikutan dari suatu perjanjian pokok yang menimbulkan kewajiban bagi para pihak untuk memenuhi suatu prestasi. Yang dimaksud prestasi adalah seperti dinyatakan pasal $1234 B W$ yakni tiap-tiap perikatan adalah untuk memberikan sesuatu, untuk berbuat sesuatu atau untuk tidak berbuat sesuatu. Jika diartikan lebih dalam lagi prestasi yang dimaksud dalam perikatan adalah segala sesuatu yang dapat dinilai dengan uang. Lembaga jaminan fidusia dapat menjamin utang piutang pada perjanjian kredit. Perjanjian kredit adalah perjanjian khusus karena pihak kreditor adalah bank dan obyek perjanjiannya adalah uang. Ketentuan-ketentuan yang diberlakukan perjanjian kredit berdasar $B W$ sebagai aturan umum, Undang-undang perbankan serta peraturan pelaksanaannya sebagai peraturan khusus. Isi perjanjian kredit biasanya sudah ditentukan oleh pihak bank dan sifatnya memaksa debitor hal ini biasa disebut sebagai kontrak standar. Perjanjian 
lahir jika kredit untuk debitor direalisasi oleh pihak bank. Hal demikian disebut perjanjian konsesuil artinya lahirnya perjanjian pada saat terjadi kesepakatan serta perjanjian obligatoir yaitu perjanjian terjadi pada saat ditanda tangani perjanjian yang mana satu orang atau lebih mengikatkan dirinya terhadap satu orang atau lebih. Perjanjian kredit bisa dilakukan dengan akta notaris ataupun dengan akta dibawah tangan.

Untuk mendapatkan dana bank bisa menggunakan fasilitas lembaga keuangan non bank yaitu Pasar Sekunder Pembiayaan Rumah. Undang-undang Republik Indonesia Nomor 4 tahun 1996 tentang Hak Tanggungan Atas Tanah Beserta Benda-benda yang Berkaitan Dengan Tanah (selanjutnya disebut UUHT) di terbitkan dengan tujuan adalah untuk memberi kedudukan bagi seorang kreditor tertentu untuk didahulukan terhadap kreditor-kreditor lain, hal ini seperti yang dinyatakan pasal 1 angka 1 UUHT menyatakan, Hak Tanggungan adalah Hak Jaminan yang dibebankan pada hak atas tanah sebagaimana dimaksud dalam Undang-undang nomor 5 tahun 1960 tentang Peraturan Dasar Pokok-pokok Agraria (selanjutnya disebut UUPA) berikut atau tidak berikut benda-benda lain yang merupakan satu kesatuan dengan tanah itu, untuk pelunasan utang tertentu, yang memberikan kedudukan yang diutamakan kepada kreditor tertentu terhadap kreditor-kreditor lain. Jika melihat rumusan pasal 1 angka 1 UUHT tersebut tujuannya adalah tidak hendak memberikan rumusan tentang hak tanggungan pada umumnya tetapi hanya membatasi dengan memberikan rumusan hak tanggungan atas tanah beserta benda-benda yang berkaitan dengan tanah saja. Sehingga ketentuan pasal 1 angka 1 UUHT 
tersebut terdapat unsur-unsur yang merupakan ciri dari hak tangggungan , yaitu :

1. Lembaga hak jaminan untuk pelunasan utang tertentu

2. Pembebanannya pada hak atas tanah

3. Berikut atau tidak berikut benda-benda lain yang merupakan satu kesatuan dengan tanah

4. Memberikan kedudukan yang preferen kepada kreditornya.

\section{Subyek hak tanggungan}

Pasal 8 dan 9 UUHT menyebutkan subyek hak tanggungan yaitu mereka yang mengikatkan diri dalam perjanjian jaminan hak tanggungan yang dalam hal ini terdiri atas pihak pemberi dan pihak pemegang hak tanggungan. Pembebanan hak tanggungan pada hak atas tanah harus dilakukan oleh pihak yang mempunyai kewenangan untuk melakukan perbuatan hukum terhadap obyek hak tanggungan dilakukan. Lahirnya hak tanggungan adalah pada saat hak tanggungan didaftarkan maka kewenangan untuk melakukan perbuatan hukum terhadap obyek hak tanggungan diharuskan ada pada pemberi hak tanggungan pada saat pembuatan buku tanah hak tanggungan. Keabsahan kewenangannya harus diperiksakan pada dimana hak tanggungan itu didaftarkan pada Kantor Pertanahan. Pemberi hak tanggungan ini bisa perseorangan atau badan hukum dengan syarat mempunyai kewenangan untuk melakukan perbuatan hukum terhadap hak atas tanah yang dimilikinya. Pemberi hak tanggungan bisa dilakukan oleh debitor pemilik hak atas tanah atau orang lain yang bersedia menjamin pelunasan utang debitor dengan membebankan tanah miliknya. Dalam hal ini yang terpenting pemberi hak tanggungan adalah mereka yang 
mempunyai kewenangan untuk melakukan perbuatan hukum terhadap hak atas tanah yang akan dijadikan jaminan pelunasan utang. Pasal 8 UUHT dan pasal $1168 \mathrm{BW}$, memberikan pengertian bahwa yang lazim pemberi hak tanggungan adalah debitor, namun subyek hukum lain dimungkinkan untuk menjadi pemberi hak tanggungan untuk menjamin pelunasan utang debitor dengan syarat pemberi hak tanggungannya mempunyai kewenangan untuk melakukan perbuatan hukum mengenai obyek hak tanggungan, karena apabila debitor wanprestasi akan mengakibatkan dijualnya obyek hak tanggungan untuk pelunasan utang yang dijamin. Dengan demikian pemberi hak tanggungan dimungkinkan orang yang bukan berutang tetapi bisa juga subyek hukum lainnya yang mempunyai kewenangan melakukan perbuatan hukum terhadap obyek hak tanggungan.

Pasal 9 UUHT menyatakan bahwa pemegang hak tanggungan adalah orang perseorangan atau badan hukum yang berkedudukan sebagai pihak yang berpiutang. Pengertian pasal tersebut subyek hukum yang berkedudukan sebagai pihak yang berpiutang dapat berupa bank, lembaga keuangan non bank, badan hukum lainnya dan perseorangan.

\section{Objek Hak Tanggungan}

Ada 2 unsur yang harus dipenuhi pada hak atas tanah agar bisa dijadikan hak tanggungan :

1. Hak tersebut harus sesuai dengan ketentuan yang berlaku dan wajib didaftarkan di Kantor Pertanahan

2. Hak tersebut menurut sifatnya harus bisa dipindahtangankan.

Obyek hak tanggungan :

1. Pasal 4 angka 1 UUHT 
a. Hak milik

b. Hak Guna Usaha

c. Hak Guna Bangunan

2. Pasal 4 angka 2 UUHT, Hak pakai atas tanah Negara yang menurut ketentuan yang berlaku wajib didaftar dan menurut sifatnya dapat dipindahtangankan.

3. Pasal 27 UUHT, Rumah susun dan Hak milik atas satuan rumah susun dan hak milik atas satuan rumah susun.

Pembebanan hak tanggungan pada hak atas tanah bisa juga benda-benda yang berkaitan dengan tanah baik yang telah ada maupun yang akan ada dikemudian hari, benda-benda yang berkaitan dengan tanah meliputi :

1. Bangunan, baik bangunan yang berada diatas tanah maupun dibawah permukaan tanah seperti basement

2. Tanaman keras

3. Hasil karya seperti candi, patung gapura

Pasal 4 angka 4 dan pasal 5 UUHT mensyaratkan agar bendabenda yang berkaitan dengan tanah tadi dapat dibebankan pula pada hak tanggungan maka harus :

1. Bangunan, tanaman dan hasil karya itu merupakan satu kesatuan dengan tanah yang bersangkutan yang dibebani dengan hak tanggungan

2. Bangunan, tanaman dan hasil karya itu merupakan milik pemegang hak atas tanah yang dibebani dengan hak tanggungan

3. Pembebanannya harus dimuat secara tegas dalam Akta Pemberian Hak Tanggungan (selanjutnya disebut APHT), jika pemiliknya lain dari pemilik hak atas tanah maka wajib dilakukan bersamaan dengan pemberian hak tanggungan atas 
tanah yang bersangkutan dan dinyatakan dalam satu APHT yang ditandatangai bersama oleh pemiliknya dan pemegang hak atas tanahnya atau kuasa mereka dengan akta otentik keduanya sebagai pihak pemberi hak tanggungan.

\section{Peralihan Hak Tanggungan}

Hak tanggungan adalah perjanjian assesoir yang mana perjanjian yang selalu mengikuti perjanjian pokoknya. Jika perjanjian pokoknya hapus maka perjanjian assesoir juga hapus begitu pula jika perjanjian pokoknya beralih maka perjanjian asesoirnya juga ikut beralih.

Pasal 16 angka 1 UUHT menyatakan hak tanggungan ikut beralih hukum kepada kreditor yang baru, jika piutang yang dijamin dengan hak tanggungan beralih karena:

1. Cessie

Penjelasan pasal 16 angka 1 UUHT, cessie adalah perbuatan hukum mengalihkan piutang oleh kreditor pemegang hak tanggungan kepada pihak lain. Menurut pasal 613 BW cessie adalah perbuatan hukum mengalihkan piutang oleh kreditor kepada pihak lain dilakukan dengan membuat sebuah akta otentik atau dibawah tangan, dengan mana hak-hak atas kebendaan itu dilimpahkan kepada orang lain. Pasal 584 BW mensyaratkan bahwa cessie merupakan suatu penyerahan hak milik yang mengikuti suatu peristiwa hukum yang bertujuan untuk mengalihkan hak milik atas suatu benda.

2. Subrogasi

Penjelasan pasal 16 angka 1 UUHT menyatakan bahwa subrogasi merupakan penggantian kreditor oleh pihak ketiga yang melunasi utang debitor, demikian juga pasal $1400 \mathrm{BW}$. 
Berarti subrogasi terjadi karena adanya pembayaran pelaksanaan atau terjadinya subrogasi dalam hal ini harus dilaksanakan menurut ketentuan yang diatur pasal $1402 B \mathrm{~W}$ yaitu subrogasi yang harus dinyatakan dengan tegas dan dilakukan tepat pada waktu pembayaran dan subrogasi yang dilaksanakan tanpa bantuan yang mempunyai piutang.

3. Pewarisan

4. Akusisi perusahaan, akibat dari akusisi tersebut menyebabkan beralihnya piutang dari perusahaan semula kepada perusahaan yang baru.

Beralihnya hak tanggungan yang diatur dalam ketentuan ini terjadi karena hukum, kondisi tersebut tidak perlu dibuktikan dengan akte yang dibuat oleh Pejabat Pembuat Akta Tanah (selanjutnya disebut PPAT). Pencatatan beralihnya hak tanggungan ini cukup dilakukan berdasarkan akta yang membuktikan beralihnya piutang yang dijamin kepada kreditor yang baru dan didaftarkan oleh kreditor pemegang hak tanggungan yang baru ke kantor pertanahan.

\section{Pendaftaran Jaminan Fiducia}

Pasal 18 UUJF menentukan bahwa publisitas merupakan persyaratan yang harus dipenuhi dalam fidusia dan segala hal yang menyangkut benda jaminan fidusia yang ada pada Kantor Pendaftaran Fidusia terbuka untuk umum. Pasal 37 UUJF menentukan jika dalam jangka waktu dimaksud tidak dilakukan penyesuaian maka perjanjian Jaminan Fidusia tersebut bukan merupakan hak agunan atas kebendaan sebagaimana dimaksud dalam Undang-undang ini, maka perjanjian jaminan fidusia yang tidak didaftarkan tidak mempunyai hak yang didahulukan baik 
didalam maupun diluar kepailitan dan atau likuidasi. Pendaftaran jaminan fidusia ini dilakukan oleh kreditor atau kuasanya atau wakilnya. Jika data-data sudah didaftarkan dan kemudian mengalami perubahan maka hal-hal yang tercantum dalam sertipikat penerima fidusia wajib mengajukan permohonan pendaftaran atas perubahan tersebut kepada kantor Pendaftaran Fidusia, pada waktu yang sama kantor Pendaftaran Fidusia melakukan pencatatan perubahan tersebut dalam buku daftar fidusia dan menerbitkan bagian tak terpisahkan dari sertipikat Jaminan Fidusia.

\section{Pasar sekunder sebagai Sarana Lembaga Pembiayaan Pemilikan Rumah}

Pemerintah telah membentuk lembaga keuangan non bank yaitu SMF dengan Peraturan Presiden Nomor 19 tahun 2005 tentang Pembiayaan Sekunder Perumahan yang diperbarui dengan Peraturan Presiden Republik Indonesia Nomor 1 tahun 2008 tentang Pembiayaan Sekunder Perumahan. Tujuan dari didirikannya SMF tersebut adalah untuk membantu penyediaan pinjaman jangka panjang kepada pihak perbankan yang menyelenggarakan KPR dalam hal penyediaan dana investasi. Hal ini sangat diperlukan karena dalam melakukan program KPR pihak bank memerlukan dana investasi jangka panjang dengan melakukan perjanjian utang piutang dengan pihak SMF. Semakin berkembangnya dunia usaha dalam menjalankan transaksi keuangan maka diperlukan suatu pranata hukum yang memadai agar para pihak terlindungi oleh hukum serta resikonya dapat diantisipasi oleh para pihak. Fungsi SMF dalam mengadakan Perjanjian Pembiayaan Sekunder Perumahan (selanjutnya disebut 
PPSP) dengan sindikasi atau korporasi perbankan penyelenggara KPR diperlukan pengamanan baik dari segi jaminan pengembalian piutangnya maupun dari segi obyek benda jaminannya, hal demikian sesuai dengan pasal 20 Perpres Nomor 1 tahun 2008 yang mensyaratkan penggunaan standarisasi dokumen yang ditetetapkan oleh PPSP dalam pemberian fasilitas pinjaman kepada penyelenggara KPR harus digunakan untuk penyaluran KPR. Penyaluran pinjaman dari SMF ke bank penyelenggara KPR ini dengan jaminan fidusia atas tagihan KPR, termasuk hak tanggungan yang melekat padanya. Pada transaksi antara debitor dan kreditor demi menjaga pengembalian dana tersebut diikat dengan hak jaminan. Jaminan adalah sarana perlindungan bagi keamanan kreditor untuk kepastian atas pelunasan utang debitor atau pelaksanaan suatu prestasi oleh debitor atau oleh penjamin debitor. Jaminan merupakan syarat yang harus dipenuhi dalam melakukan perjanjian utang piutang. Jaminan merupakan pendukung pengembalian utang jika penilaian kelayakan usahanya atas debitor kurang mendukung lagi untuk pengembalian utang dalam rangka menarik kembali dana yang telah disalurkan.

Untuk mengantisipasi dalam menarik kembali dana yang telah disalurkan kepada debitor ada 2 faktor yang harus dipertimbangkan :

1. Scured yaitu jaminan kredit dapat diadakan pengikatan secara yuridis formal sesuai ketentuan hukum dan perundangundangan yang berlaku, jika dikemudian hari debitor melakukan wanprestasi maka kreditor memiliki kekuatan yuridis dalam melakukan eksekusi benda jaminan. 
2. Marketable yaitu jaminan tersebut jika hendak dieksekusi dapat segera dijual atau diuangkan untuk melunasi seluruh kewajiban debitor.

Pada proses Perjanjian Pemberian Pinjaman ini terdapat 2 perjanjian:

1. Perjanjian antara penyelenggara KPR dan nasabahnya

2. Pemberian fasilitas pinjaman dari SMF kepada penyelenggara KPR

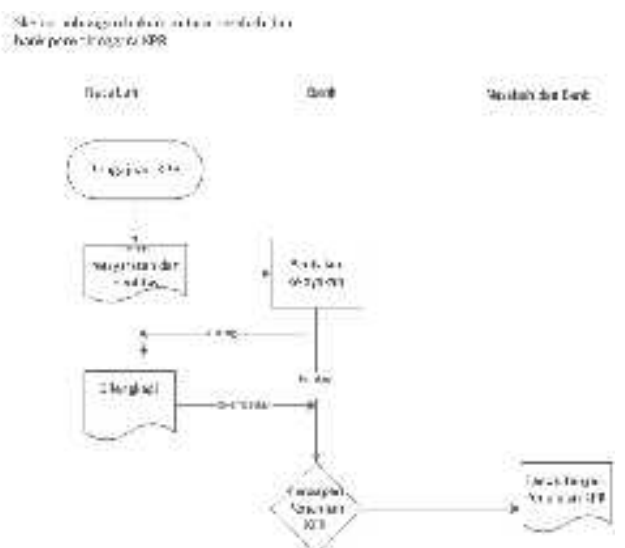

Gambar 1. : Skema hubungan hukum antara nasabah dan Bank penyelenggara KPR

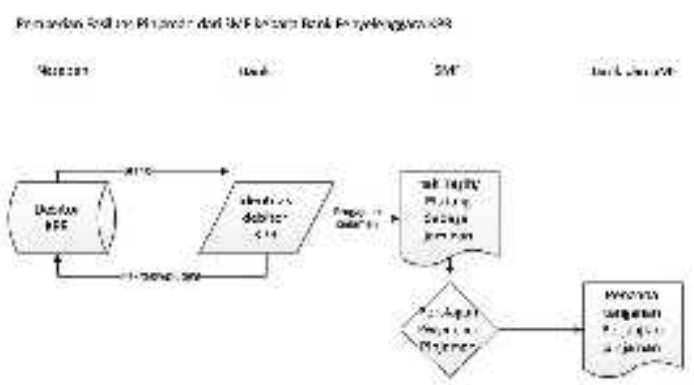

Gambar 2. Skema Pemberian Fasilitas Pinjaman SMF kepada Bank Penyelenggara KPR

Perjanjian tersebut masing-masing berdiri sendiri meskipun timbulnya perjanjian kedua berkaitan dengan perjanjian pertama 
dan perjanjian kedua juga dijamin oleh ikatan yang terdapat dalam perjanjian pertama sehingga dua perbuatan hukum tersebut terpisah tetapi berkaitan dalam proses dan akibat hukumnya. Dalam perjanjian pemberian KPR yang dijadikan obyek jaminan dari nasabah KPR kepada penyelenggara KPR adalah tanah dan bangunan. Tanah dan bangunan tersebut dijaminkan sebagai upaya awal sewaktu-waktu dapat dieksekusi atau dijual kembali oleh pihak penyelenggara KPR apabila nasabah KPR melakukan wanprestasi untuk pelunasan kredit yang telah diberikan pada pembelian rumah tersebut. Lembaga jaminan yang dibebankan atas rumah obyek KPR adalah hak tanggungan. Sedangkan dalam perjanjian pemberian fasilitas pinjaman dari SMF kepada penyelenggara KPR yang dijadikan jaminan adalah piutang. Piutang yang sudah ada maupun yang akan ada yang dimiliki penyelenggara KPR termasuk hak tanggungan atas obyek KPR dikategorikan sebagai asset keuangan penyelenggara KPR. Lembaga jaminan yang dapat dibebankan pada piutang adalah jaminan fidusia.

\section{KESIMPULAN}

1. Perjanjian antara Bank Penyelenggara KPR dan nasabahnya berdiri sendiri namun saling berkaitan dengan perjanjian yang dibuat antara Bank Penyelenggara KPR dan SMF. Perjanjian yang dibuat tersebut menimbulkan jaminan dalam perjanjian pemberian pinjaman yaitu jaminan tanggungan dan jaminan fidusia yang merupakan perjanjian assesoir dari perjanjian pokok yang berbeda. Hak tanggungan atas obyek KPR merupakan perjanjian assesoir dari perjanjian KPR antara penyelenggara KPR dengan nasabah KPR, sedangkan piutang 
atau hak tagih yang dijadikan obyek jaminan fidusia merupakan perjanjian assesoir dari perjanjian Pemberian Pinjaman antara SMF dan penyelenggara KPR.

2. Perjanjian antara Bank Penyelenggara KPR dengan SMF merupakan perjanjian biasa yakni Perjanjian Peminjaman, hal ini sesuai dengan tujuan SMF didirikan karena untuk memberikan fasilitas pinjaman untuk bank penyelenggara KPR.

3. Piutang merupakan benda tak berwujud yang dapat dijadikan jaminan Fidusia, hal demikian terjadi karena Fidusia atas dasar kepercayaan yang penyerahan jaminannya kepada kreditor bersifat constitutum posesorium, penyerahannya sudah memenuhi semua syarat-syarat tetapi hanya dimaksudkan sebagai jaminan saja.

4. Apabila terjadi wanprestasi oleh nasabah KPR maka penyelenggara KPR dapat mengeksekusi hak tanggungan atas obyek KPR untuk melunasi utangnya kepada SMF, sedangkan apabila penyelenggara KPR lalai melakukan pelunasan atas pinjaman yang diberikan oleh SMF maka SMF dapat mengeksekusi jaminan fidusia atas tagihan KPR tersebut. Selama jaminan fidusia tetap berada ditangan SMF, hak tanggungan tetap berada pada penyelenggara KPR, hak tanggungan baru beralih kepada kreditor baru apabila jaminan fidusia telah dieksekusi dan tagihan KPR yang menjadi obyek jaminan fidusia tersebut dibeli oleh pihak lain. 


\section{DAFTAR PUSTAKA}

Badrulzaman, Mariam Darus, BW Buku III, Hukum Perikatan Dengan Penjelasan, Alumni, Bandung, 1996 , Aneka Hukum Bisnis, Alumni, Bandung, 1994

Bahsan, M, Hukum Jaminan dan Jaminan Kredit Perbankan Indonesia, Radja Grafindo Persada, Jakarta, 2007

Djumhana, Muhamad, Hukum Perbankan di Indonesia, Citra Aditya Bakti, Bandung, 2006

Ginung Pratidina, Fidusia Sebagai Lembaga Jaminan Atas Bangunan Diatas Tanah Hak Sewa, Skripsi, Fakultas Hukum, Universitas Brawijaya, Malang, 1987

Hernoko, Agus Yudha, Hukum Perjanjian Asas Proporsionalitas dalam Kontrak Komersial, Kencana Media Prenada Group, Cetakan 2, Jakarta, 2011

Iriawan, Wawan,Cessie, Piutang Kredit, Hak dan Perlindungan Bagi Kreditor Baru, Jambatan, Jakarta, 2005

Mulyadi, Kartini dan Gunawan Wijaya, Seri Hukum Perikatan, Perikatan Yang Lahir Dari Perjanjian, Raja Grafindo Persada, Jakarta, 2002 ., Seri Hukum Perikatan, Penanggungan Utang Dan Perikatan Tanggung Menanggung, Raja Grafindo Persada, Jakarta, 2002 ., Hukum Jaminan, Hak-hak Jaminan Pribadi, Tentang Perjanjian Penanggungan Dan Perikatan Tanggung

Menanggung, Citra Aditya Bakti, Bandung, 2003 , Seri Hukum Harta Kekayaan, Hak Tanggungan,

Kencana Prenada Media Group, Jakarta, 2006 
Oey Hoey Tiong, Fidusia Sebagai Jaminan Unsur-unsur Perikatan, Ghalia Indonesia, Cet. 2, 1985

Prajitno, Andi A.A., Hukum Fidusia, Problematika Yuridis Pemberlakuan Undang-undang Nomor 42 Tahun 1999, Banyumedia Publishing, Surabaya, 2009

Satrio, Hukum Hak-Hak Jaminan Kebendaan, Citra Aditya Bakti, Bandung, 1993

, Cessie, Subrogatie, Novatie, Kompensatie \& Percampuran Hutang, Alumi, Bandung, 1999

Suharnoko dan Endah Hartati, Doktrin Subrogasi, Novasi dan Cessie, Prenada Media, Jakarta, 2005

Simamora, Yohanes Sogar, Hukum Perjanjian, Prinsip Hukum Kontrak Pengadaan Barang dan Jasa Oleh Pemerintah, LaksBank Presindo, Jogjakarta, 2009

Sjahdeni, Remy ST, Hak Tanggungan Asas-asas, Ketentuanketentuan pokok dan masalah yang dihadapi oleh Perbankan, Alumni, Bandung, 1999.

Sri Sudewi Machsun Sofyan, Himpunan Karya Tentang Hukum Jaminan, Liberty, Yogyakarta, 1982

Subekti, Hukum Perjanjian, Cet. 19, Intermasa, Jakarta, 2002

Soewarso, Indrawati, Aspek Hukum Jaminan Kredit, Institut

Bankir Indonesia, Jakarta, 2002

Subekti dan Tjitrosudibjo, Kitab Undang-undang Hukum Perdata, Pradnya Paramita, Jakarta, 1980, Lembaran Negara RI Tahun 1974 Nomor 1

Tan Kamelo, Hukum Jaminan Fidusia, Suatu Kebutuhan Yang Didambakan, Alumni Bandung 2004

Widyadharma,Ignatius Ridwan, Hukum Jaminan Fidusia, Badan Penerbit Universitas Diponegoro, Semarang, 1999 
Widjaya Gunawan dan Ahmad Yani, Seri Hukum Bisnis Jaminan Fidusia, Raja Grafindo Persada, Jakarta, 2000.

Peraturan dan Perundang-undangan

Undang-undang Nomor 4 tahun 1996 tentang Hak Tanggungan Atas Tanah Beserta Benda-benda yang berkaitan dengan Tanah. Lembaran Negara Republik Indonesia , Tahun 1996, Nomor 42, Tambahan Lembaran Negara RI tahun 1996 nomor 3632

Undang-undang No. 42 tahun 1999 tentang Jaminan Fidusia, Lembaran Negara Republik Indonesia, tahun 1999, nomor 168, Tambahan Lembaran Negara RI nomor 3889

Peraturan Presiden Republik Indonesia Nomor 19 tahun 2005 Tentang

Pembiayaan Sekunder Perumahan, Lembaran Negara Republik Indonesia, tahun 2005, Nomor 21, Tambahan Lembaran Negara RI nomor 4479

Peraturan Presiden Republik Indonesia Nomor 1 tahun 2008 tentang Perubahan Atas Peraturan Presiden Nomor 19 Tahun 2005 Tentang Pembiayaan Sekunder Perumahan 
